\section{BUILDING THE URBAN FUTURE AND TRANSIT ORIENTED DEVELOPMENT (BUFTOD 2012)}

The International Scientific Conference Building the Urban Future and Transit Oriented Development (BUFTOD 2012) with subtitle Rail and other modes, connecting with urban and regional development was held in Paris in the region of Marne la Vallee on 16 and 17 April 2012 at Ecole Nationale des Ponts et Chaussées (ENPC). The Conference was organized by: Institut français des sciences et technologies des transports, de l'aménagement et des réseaux (IFSTTAR), Laboratoire Ville Mobilite Transport (LVMT), Futurs Urbains, Universite Paris-Est, Technische Universität München, Ecoles des Ponts Paris Est and Universidad Autónoma de Ciudad Juárez (UACJ).

The Conference gathered the scientists from the field of Transit Oriented Development with emphasis on the creation of the sustainable urban and regional development with the support of public transit, and especially by using the railway as the carrier of traffic load and other complementary modes. The scientists came from Europe (France, Germany, Switzerland, Italy, Great Britain, the Netherlands, Belgium, Spain, Russia, Portugal, Finland and Croatia), from America (the United States of America, Mexico, Columbia and Brazil), and from Asia (Israel, South Korea and Pakistan).

The plenary session was organised around a series of keynote speeches with: Robert Cervero, University of California at Berkeley: "A Panorama of TOD Principles \& Experiences"; Claude Soulas, IFSTTAR-GRETTIA: "Evolution of the different transport modes to be taken into account for TOD, and combination with intermo- dality"; Fernando Lozada Islas, Universidad Autonoma de Ciudad Juarez: "TOD \& Smart Growth - A look at the Latin American experience" and Gebhard Wulfhorst, Technische Universität München and Alain L'Hostis, IFSTTAR-LVMT: “The Bahn.Ville approach of an urbanism oriented towards rail and intermodality - key findings of the French-German cooperation".

In his first presentation Robert Cervero explained the concept of Transit Oriented Development which presented the rational consideration of the traffic system development, and from the US viewpoint it does not mean that the significance of road traffic is decreasing. The especially important factor of Transit Oriented Development is the study of the transport demand. Then he presented different systems around the World and gave their critical evaluation. He especially emphasised the fact that often Transit Oriented Development is explained as social engagement, and Transit Oriented Development represents in fact the possibility of choosing the transport mode.

The Conference audience was then addressed by Claude Soulas who considered strategically the Transit Oriented Development. He provided a philosophical approach to the problem of time horizons for the strategies of public transport systems. In the context of strategic thinking he presented the information of the French Ministry of Health that every human should walk at least 30 minutes per day for their health which excellently fits the Transit Oriented Development strategy. As conclusion, he emphasised that there are numerous results that can be applied in the Transit Oriented Development strategy, but such development should be considered from the local context.

Public transport systems in Latin America were presented by Fernardo Lozada Islas who analyzed the

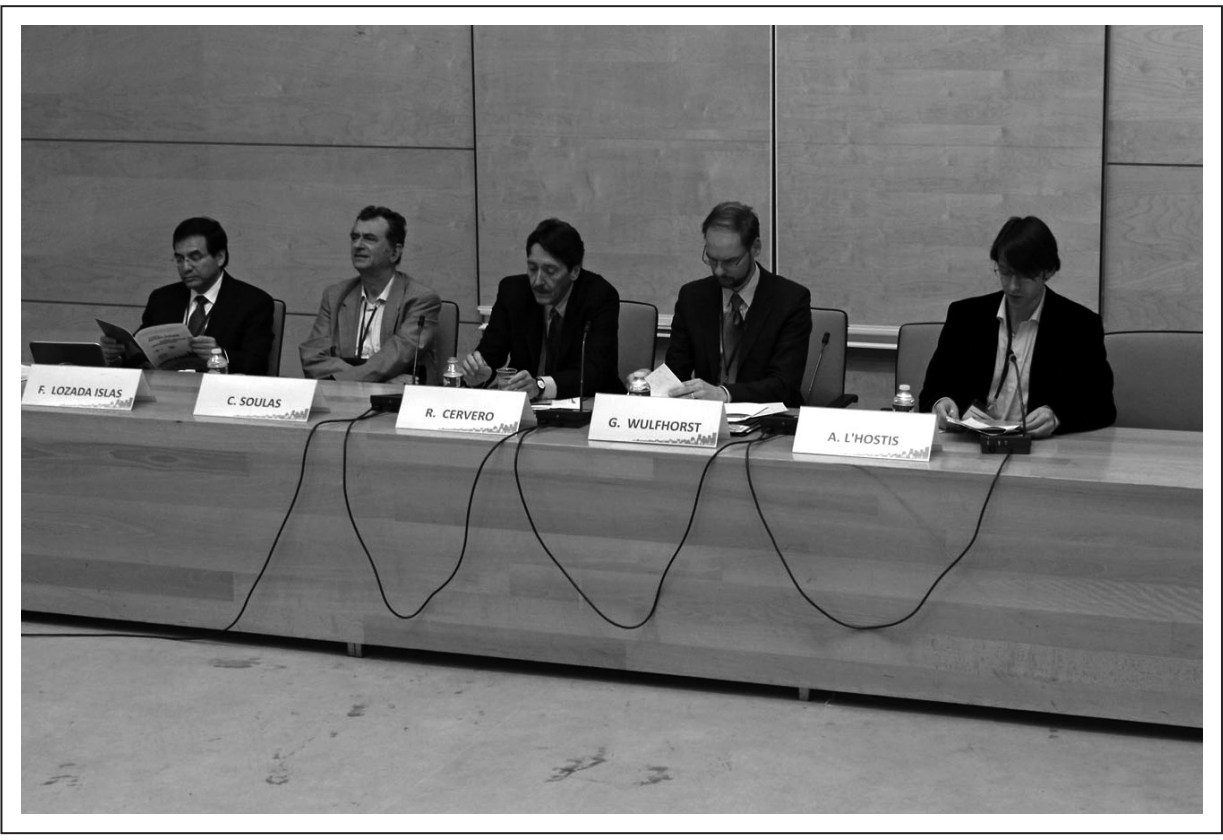

The plenary session speakers 
closed systems with buses (Bus rapid transit - BRT). He made a special analysis between other public systems (tram, urban rail, ...) with the closed bus systems. Then he presented comparative analysis of such systems in Latin American countries.

The last presentation in the plenary session was given by Alain L'Hostis and Gebhard Wulfhorst with the topic of the French-German project Bahn.Ville. The project has been carried out over the last 10 years and had as its objective the rail-oriented development and intermodality in urban regions. The study included especially various legal solutions of the public transport system in France and Germany. Then the criteria of public transport development were analyzed with the railway as the carrier of transport load. These criteria were tested on two railway lines, one in France and the other in Germany.

The Conference was divided into six sessions: A Urban models, urban utopias and the city of tomorrow,
B - Influence of TOD on transit use (mobility), C - Location of activities, urban mix, D - Conception of public space and built environment for TOD, E - TOD applied to different territories: corridors, regions, and agglomerations, F - Transport systems in the context of TOD: rail, bus and intermodality and G - Planning the TOD, procedures and involvement of actors.

The presentations were followed by discussions about the papers and at the end of every session conclusions were formed from the presented papers.

At the end of the Conference there was a final session. It was concluded that the papers presented at the Conference studied various aspects of Transit Oriented Development and set certain solutions and opened up new research issues.

\section{Asst. Prof. Borna Abramović, Ph.D. University of Zagreb, Faculty of Transport and Traffic Sciences, Zagreb, Croatia}

